Article

\title{
Plato's Visible God: The Cosmic Soul Reflected in the Heavens
}

\section{George Latura}

32 Hemlock Trail, Trumbull, CT 06611, USA; E-Mail: glbeke@ me.com; Tel.: +1-203-385-3884

Received: 19 July 2012; in revised form: 27 August 2012 / Accepted: 3 September 2012 /

Published: 14 September 2012

\begin{abstract}
Although Plato states that the perceptible god that he describes in Timaeus is visible to the human eye, the reflection of the Cosmic Soul in the heavens has largely been explained away or forgotten in the Western mind. But Roman texts, early Christian testimony, and Imperial coins illustrate that Plato's intersection in the heavens played a major role in Hellenistic cosmology and soteriology.
\end{abstract}

Keywords: Plato; Visible God; Cosmic Soul; zodiacal light; Milky Way; intersection

\section{The World Soul: Justin Martyr, Proclus and Plato}

In an open letter addressed to the Roman emperor Antoninus Pius, the Christian apologist Justin Martyr argued that the celestial X in Plato's Timaeus was a foreshadowing of the Christian cross, a shape that Plato had somehow pilfered from Moses.

And the scientific discussion of the Son of God in his Timaeus - when he says: "He arranged him as an X in the whole"-Plato took from Moses, and spoke in similar terms. - Justin Martyr, Apology on Behalf of Christians ([1], p. 235)

Here Justin conflates the Christian Son of God with Plato's Cosmic Soul, and he provides evidence that, in the glory days of the Roman Empire, Plato's Anima Mundi was seen as composed of intersecting lines in the heavens.

At the twilight of the Empire, the Platonic successor Proclus likewise connected Plato's intersecting symbol with the cosmic realm.

The shape $\mathrm{X}$ itself that results from the affixing [of the two strips] has the highest degree of appropriateness to the universe and to the soul.-Proclus, Commentary on Plato's Timaeus ([2], p. 233) 
The $\mathrm{X}$ in the universe that Proclus is commenting on and the Son of God that Justin Martyr places like an X in the cosmos both refer to the passage in Plato's Timaeus that describes the creation of the World Soul.

Next, he sliced this entire compound in two along its length, joined the two halves together center to center like an X, and bent them back in a circle, attaching each half to itself end to end and to the ends of the other half at the point opposite to the one where they had been joined together. He then included them in that motion which revolves in the same place without variation, and began to make one the outer, and the other the inner circle. And he decreed that the outer movement should be the movement of the Same, while the inner one should be that of the Different.-Plato, Timaeus ([3], p. 21)

Here Plato positions two cosmic circles at an angle to each other so that they intersect "like an X." What might these two circles stand for?

\section{Modern and Ancient Mis-Interpretation}

One interpretation, put forth by R. G. Bury in 1929 and Francis Cornford in 1937, maintains that Plato's celestial $\mathrm{X}$ is formed by the intersection of the celestial/sidereal equator and the ecliptic/zodiac.

He now tilts the inner band, so that it makes an oblique angle with the outer, which is set at the horizontal; from which we see that the Revolution of the Same represents the celestial Equator, moving "horizontally to the right" (from East to West), and the Revolution of the Other represents the Ecliptic, which moves in a contrary direction to the Equator (from West to East), and at an angle to it. The Ecliptic He divides into seven, to represent the seven planets. - Bury, Plato: Timaeus ([4], p. 72, n. 1)

Timaeus now speaks as if the Demiurge had made a long band of soul-stuff, marked off by the intervals of his scale. This he proceeds to slit lengthwise into two strips, which he puts together by their middles and bends round into two circles or rings, corresponding to the sidereal equator and the Zodiac.-Cornford, Plato's Cosmology ([5], p. 72)

Plato makes no mention of the celestial equator, yet influential books on the cult of Mithras in the Roman Empire were released by David Ulansey [6] and Roger Beck [7], with the Bury/Cornford interpretation championed by both Ulansey ${ }^{1}$ and Beck. ${ }^{2}$

Where might Bury and Cornford have found this interpretation of Plato's X? Perhaps in the works of Proclus, whose Commentary on Plato's Timaeus [2] already espoused this view.

Now surely two circles come into being, and these have come to be in such a way that one is on the inside and the other is on the outside, and they are at an angle to one another. Now one of these is called the circle of the Same and the other is the circle the Different. The one corresponds to the equator while the other corresponds to the circle of the ecliptic. The entire circle of the Different is carried around the ecliptic, while the circle of the Same is carried around the equator. Because of this it is immediately evident that it is not necessary to assume these circles to be at right angles to one another, but rather like an X, just as Plato said...-Proclus, Commentary on Plato's Timaeus ([2], p. 222).

1 "The celestial equator and the ecliptic intersect at two points..." ([6], p. 47)

2 "The model... is essentially that established by Plato in the Timaeus... It even has its standard iconographic representation: the world globe with the crossed bands of equator and ecliptic/zodiac.” ([7], p. 79) 
Proclus' equator and Cornford's sidereal equator refer to the celestial equator, a projection of the Earth's equator into the heavens, showing that Proclus and Bury and Cornford (and Ulansey and Beck) all agree that Plato's $\mathrm{X}$ is composed of the path of the planets (the ecliptic that traces out the zodiac) and the celestial equator.

But Plato's own words prove this view to be in error.

At the end of Timaeus, Plato proclaims that the living Cosmos (which he said had the shape of an $\mathrm{X})$ is a visible, discernible god.

And so now we may say that our account of the universe has reached its conclusion. This world of ours has received and teems with living things, mortal and immortal. A visible living thing containing visible ones, perceptible god, image of the intelligible Living Thing... Our one heaven, indeed the only one of its kind, has come to be.-Plato, Timaeus ([3], p. 88)

But since the celestial equator is a mathematical calculation and a geometric projection, it is certainly not visible in the heavens - exposing the fallacy behind the interpretation of Proclus, Bury, Cornford, Ulansey, Beck, etc.

\section{Correct Interpretation}

Who should we look to for the correct explanation? To Plato himself, whose narrative emphasizes that the Cosmic Soul, which has the shape of an X, will find a visible manifestation in the heavens.

The Demiurge first creates the World Soul, composed of two cosmic circles whose intersections take the form of an X. According to Plato, the Cosmic Soul itself is invisible, but the Creator decides to make the visible body of the universe as similar as possible to the invisible soul.

Now while the body of the universe had come to be as a visible thing, the soul was invisible.-Plato, Timaeus ([3], p. 23)

Now when the Father who had begotten the universe observed it set in motion and alive, a thing that had come to be as a shrine for the everlasting gods, he was well pleased, and in his delight he thought of making it more like its model still. So, as the model was itself an everlasting Living Thing, he set himself to bringing this universe to completion in such a way that it, too, would have that character to the extent that was possible.-Plato, Timaeus ([3], pp. 23-24)

In other words, the visible body of the universe mirrors as closely as possible the form of the invisible Cosmic Soul, whose two intersecting circles give the shape of an X. To give us a clue as to the components of this cosmic scheme, Plato reveals that one of the celestial circles, the circle of the Different, follows the path of the Wanderers, the seven Planets that trace out the zodiac.

When the god had finished making a body for each of them, he placed them into the orbits traced by the period of the Different—-seven bodies in seven orbits.—Plato, Timaeus ([3], p. 25)

But does the course of the Planets ever become visible, as Plato stipulates?

And what other visible circle in the sky intersects the planetary path to form an $\mathrm{X}$, the shape of the Cosmic Soul that is mirrored in the heavens?

We can thank our lucky stars that the Roman writer Manilius penned an exposition of the art of astrology around the time of Augustus. At the beginning of his esoteric tome, Manilius emphatically 
describes two visible circles that intersect in the heavens. One is the path of the Planets and the other is the Milky Way.

To these [previous circles] you must add two circles which lie athwart and trace lines that cross each other. One contains the shining signs through which the Sun plies his reins, followed by the wandering Moon in her chariot, and wherein the five planets which struggle against the opposite movement of the sky perform the dances of their orbits that nature's law diversifies... Nor does it elude the sight of the eye, as if it were a circle to be comprehended by the mind alone, even as the previous circles are perceived by the mind: nay, throughout its mighty circuit it shines like a baldric studded with stars and gives brilliance to heaven with its broad outline standing out in sharp relief.

The other circle [the Milky Way] is placed crosswise to it. -Manilius, Astronomica ([8], pp. 57, 59)

Certainly the Via Galactica is visible even today at a good distance from light-polluting cities, and since this awesome apparition in the night sky partakes of the revolution of the fixed stars-Plato's motion of the Same-it becomes evident that the Milky Way is the component of Plato's visible celestial X that intersects the path of the Planets.

What is the other celestial apparition that is as visible as Manilius claims?

\section{Zodiacal Light and Milky Way}

The Wanderers along the ecliptic map out the constellations of the Zodiac, but neither the planets themselves nor the zodiacal constellations give the "brilliance to heaven... standing out in sharp relief' that Manilius paints before our eyes. What celestial phenomenon might explain Manilius' exuberant evocation?

That would be a rare and miraculous-seeming event that occurs only at specific times of the year. In temperate zones, the zodiacal light illuminates the sky along the ecliptic shortly before dawn or soon after dusk, depending on the season.

Enveloping the planets along its path, this broad swath of interplanetary dust reveals the stairway to heaven along which the souls of the just climb to the Milky Way, the celestial abode according to Cicero (Dream of Scipio), Manilius (Astronomica), Ovid (Metamorphoses), Macrobius (Commentary on the Dream of Scipio), Martianus Capella (Marriage of Philology and Mercury), etc.

And when the heavenly intersection reveals itself at rare times of the year, we witness Plato's visible, perceptible god - the embodiment of the Cosmic Soul - that, according to Justin Martyr, looks like "an X" (Figure 1).

Plato's perceptible god, the visible intersection in the sky, appeared on coins of the Roman Empire for hundreds of years (Figure 2), on coins minted by Antoninus Pius, Marcus Aurelius, Macrinus, and other emperors.

In his plea to the Roman emperor, Justin Martyr gives us not only Plato's visible god placed "as an $\mathrm{X}$ " in the heavens, as shown on imperial coins, he also testifies to a most important use of the intersecting symbol in the Roman world.

And you set up the images of your dead emperors on this pattern, and you name them gods through inscriptions. —Justin Martyr, Apology on Behalf of Christians ([1], p. 227) 
Figure 1. The zodiacal light rises from the horizon, envelops planets along the ecliptic, and intersects the Milky Way, revealing Plato's visible god, the celestial X that mirrors the World Soul. (Photo: Matt BenDaniel).

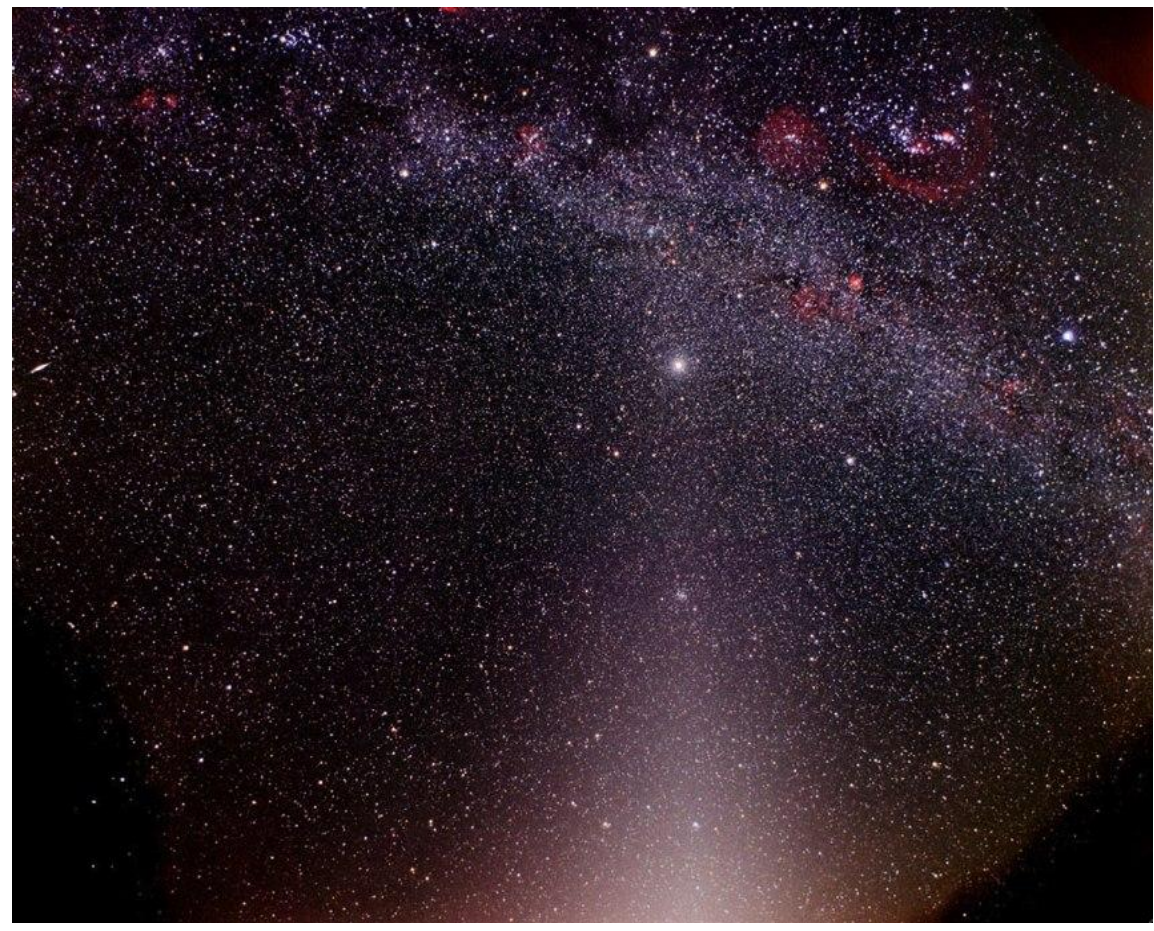

Figure 2. Plato's $X$ on Roman coins. Left: Denarius of Antoninus Pius, with Italia enthroned on celestial sphere with intersecting lines (RIC III [9] \#98a). Middle: Coin of Marcus Aurelius, with Providentia pointing to the celestial sphere with intersecting lines (RIC III [9] (Pius) \#446). Right: Coin of Macrinus, with Providentia pointing to cosmic orb with intersecting lines (RIC IV Pt 2 [10] \#80).
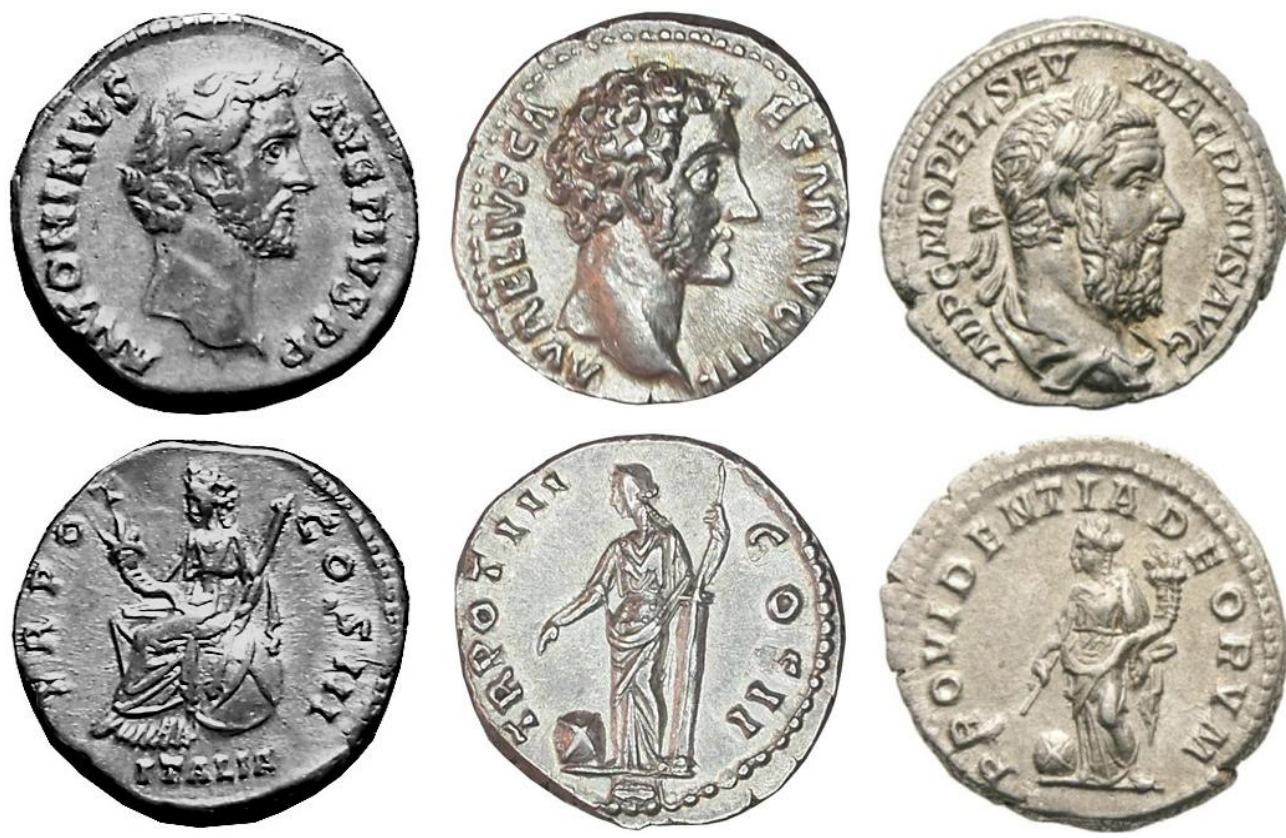
Invoking the sacred intersection struck on imperial coins of his day, Justin points to a crucial ritual in Roman religious life, one that harkened back to the funeral of Augustus himself. When a beloved emperor died, an eagle was released as the pyre consumed the physical body, to portray the soul of the emperor being carried by the bird of Jupiter to the company of the gods.

The Roman Senate deified admired rulers with the title divus, or divine, in the process of consecratio (Figure 3). The cosmic orb, with the intersecting lines that Justin Martyr refers to in his public letter, stood for the World Soul that encompassed the heavens where the emperor would enjoy eternal life among the gods.

Figure 3. A consecratio denarius declares Marcus Aurelius a divine being (divus), while Jupiter's eagle sits atop the celestial orb with intersecting lines: Plato's X, the visible reflection of the Cosmic Soul in the heavens (RIC III [9] (Commodus) \#273).
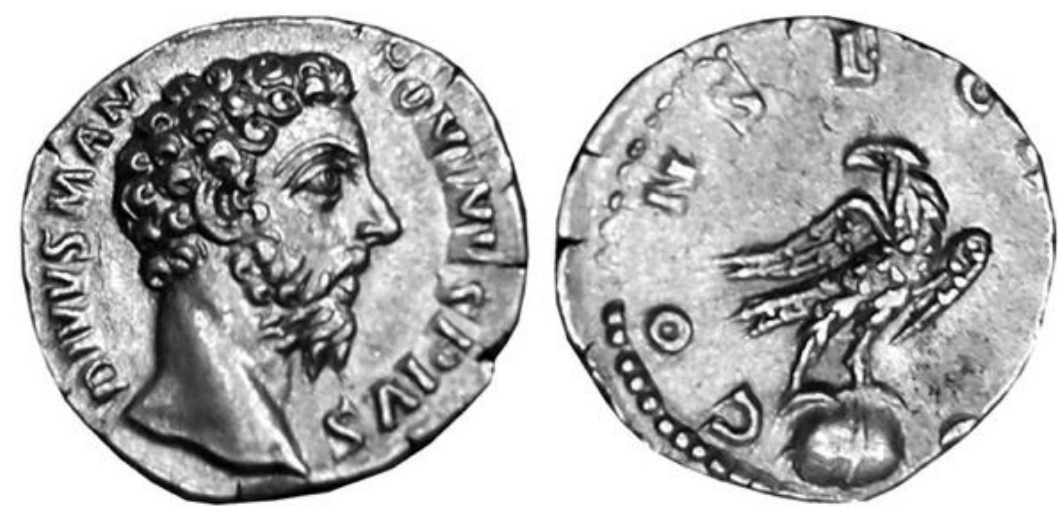

\section{Conclusions}

With Justin Martyr's testimony, we can connect the consecratio coins of Roman emperors to the celestial intersecting symbol that indicates Plato's perceptible god. In this symbolism, we see the soul of the emperor joining the gods in the heavens, with the visible $\mathrm{X}$ indicating Plato's Cosmic Soul.

More than a hundred years after Justin Martyr's revisionist attempt, the Christian bishop Lactantius again sought to recast Plato's celestial X into a Christian symbol. ${ }^{3}$ Following the lead of Lactantius, the bishop Eusebius of Caesaria conjured a masterpiece of propaganda ${ }^{4}$ that would eclipse the memory of Plato's visible cosmic intersection and erase it from the Western mind for more than a millennium and a half.

The tradition of distorting Plato's celestial intersection into a Christian symbol endures in Bury's translation of Timaeus (1929), where Plato's X is mistranslated as "like a great cross" ([4], p. 71).

3 "Constantine was advised in a dream to mark the heavenly sign of God on the shields of his soldiers and then engage in battle. He did as he was commanded and by means of a slanted letter X with the top of its head bent around, he marked Christ on their shields. Armed with this sign, the army took up its weapons."-Lactantius, De Mortibus Persecutorum ([11], p. 63)

4 "About the time of the midday sun, when day was just turning, he said he saw with his own eyes, up in the sky and resting over the sun, a cross-shaped trophy formed from light, and a text attached to it which said, 'By this conquer'." -Eusebius, Life of Constantine ([12], p. 81) 
Thanks to the Astronomica of Manilius, however, we can be sure that Plato's celestial X was composed of the intersection of two visible celestial circles: the Milky Way and the zodiacal light that illuminates the path of the Planets, the two perceptible structures in the heavens that embody Plato's Visible God.

\section{References and Notes}

1. D. Minns, and P. Parvis, eds. Justin, Philosopher and Martyr: Apologies. New York: Oxford University Press, 2009.

2. D. Baltzly, trans. Proclus: Commentary on Plato's Timaeus: Volume 4, Book 3, Part 2, Proclus on the World Soul. New York: Cambridge University Press, 2009.

3. D.J. Zeyl, trans. Plato: Timaeus. Indianapolis: Hackett Publishing Company, 2000.

4. R.G. Bury, trans. Plato: Timaeus, Critias, Cleitophon, Menexenus, Epistles. Cambridge: Harvard University Press, 1929.

5. F.M. Cornford. Plato's Cosmology: The Timaeus of Plato. London: K. Paul, Trench, Trubner, 1937.

6. D. Ulansey. The Origins of the Mithraic Mysteries. New York: Oxford University Press, 1989.

7. R. Beck. The Religion of the Mithras Cult in the Roman Empire. New York: Oxford University Press, 2006.

8. G.P. Goold, trans. Manilius: Astronomica. Cambridge: Harvard University Press, 1977.

9. H. Mattingly, and E.A. Sydenham. The Roman Imperial Coinage: Antoninus Pius to Commodius. London: Spink \& Son, 1930, Vol. III.

10. H. Mattingly, E.A. Sydenham, and C.H.V. Sutherland. The Roman Imperial Coinage: Macrinus to Pupienus. London: Spink \& Son, 1938, Vol. IV, Part 2.

11. J.L. Creed. Lactantius: De Mortibus Persecutorum. New York: Oxford University Press, 1984.

12. A. Cameron, and S.G. Hall, trans. Eusebius: Life of Constantine. New York: Oxford University Press, 1999.

(C) 2012 by the author; licensee MDPI, Basel, Switzerland. This article is an open access article distributed under the terms and conditions of the Creative Commons Attribution license (http://creativecommons.org/licenses/by/3.0/). 